A N N A L ES

UNIVERSITATIS MARIAE CURIE-SKŁODOWSKA LUBLIN - POLONIA

VOL. LXIII, 2

SECTIO G 2016

Uniwersytet Marii Curie-Skłodowskiej w Lublinie

zbigniew.kmiecik@poczta.umcs.lublin.pl

marta.grzeszczuk@poczta.umcs.lublin.pl

ewelina.streit-browarna@umcs.pl

ZBIGNIEW ROMUALD KMIECIK, MARTA GRZESZCZUK,

EWELINA STREIT-BROWARNA

\title{
Klauzula generalna interesu społecznego w postępowaniu administracyjnym, sądowoadministracyjnym oraz egzekucyjnym $\mathrm{w}$ administracji
}

General Clause of Social Interest in the General Administrative Proceedings, the Proceedings before Administrative Courts and the Administrative Executive Proceedings

\section{WPROWADZENIE}

Wśród zwrotów niedookreślonych znajdują się takie, których stosowanie nie wiąże się ani z kwalifikowaniem wielkości, ani doprecyzowaniem pasa nieostrości. Mowa tu o zwrotach niedookreślonych odsyłających, których wystąpienie $\mathrm{w}$ przepisie prawnym wiąże się z nakazem uwzględnienia tego, do czego prawodawca za pomocą tych zwrotów odsyła ${ }^{1}$.

Klauzule generalne nie są również związane z odesłaniem pozasystemowym do zwyczajów czy obyczajów. W tym przypadku także następuje odesłanie do jakiegoś zbioru norm pozaprawnych, których adresaci mają obowiązek przestrzegać. Jeżeli w przepisie prawnym znajduje się odesłanie do tych norm, to podmiot stosujący prawo musi uwzględnić ich treść po uprzednim odszukaniu i ustaleniu, czy w danym przypadku będą miały zastosowanie. Nie jest to jednak sytuacja związana ze stosowaniem przez prawodawcę klauzul generalnych w celu

1 A. Choduń, A. Gomułowicz, A. Skoczylas, Klauzule generalne i zwroty niedookreślone w prawie podatkowym i administracyjnym. Wybrane zagadnienia teoretyczne i orzecznicze, Warszawa 2013, s. 26. 
uelastycznienia tekstu aktu prawnego, lecz z otwarciem tego tekstu na normy pozaprawne ${ }^{2}$.

Zdarza się, że ustawodawca obok jednej klauzuli generalnej umieszcza i inne, tworząc niekiedy swoisty łańcuch klauzul generalnych, np. organ administracji publicznej podejmuje tylko czynności niecierpiące zwłoki ze względu na interes społeczny lub słuszny interes strony. Obok nazwy nieostrej „czynności niecierpiące zwłoki" zostały użyte dwie klauzule generalne, a mianowicie ,interes społeczny” lub „słuszny interes strony”, co w kontekście interpretacji będzie pociągało za sobą różne konsekwencje 3 .

Generalnymi klauzulami odsyłającymi występującymi w polskich tekstach przepisów prawnych są między innymi odesłania do: zasad współżycia społecznego, interesu społecznego, interesu publicznego, dobra dziecka, dobra rodziny, dobrych obyczajów, sprawiedliwości społecznej itp. ${ }^{4}$

\section{KLAUZULA INTERESU SPOŁECZNEGO W OGÓLNYM POSTĘPOWANIU ADMINISTRACYJNYM}

Analizując kwestię miejsca, jakie zajmuje pojęcie interesu społecznego w jurysdykcyjnym postępowaniu administracyjnym, niewątpliwie przydatne, a może nawet niezbędne, zdaje się być określenie, przynajmniej w zarysie, jego sfery granicznej. Z racji jego nieostrości proces nie tyle zdefiniowania, co określenia granic tego pojęcia, jest niezwykle trudny. Skomplikowana i dynamiczna jego treść niejednokrotnie obejmuje wartości indywidualne, interesy poszczególnych ludzi bądź grup społecznych. Pojęcie interesu społecznego należy do kategorii pojęć niezdefiniowanych, jego treść ustala organ orzekający ${ }^{5}$.

W wielu regulacjach prawnych są zawarte tzw. zwroty nieostre, inaczej określane jako „wyrażenia nieostre”, „Zwroty niedookreślone”. Zdaniem M. Mincer za najbardziej prawidłowe należy uznać posługiwanie się nazwą ,pojęcia”, ponieważ obejmują one znaczenia terminów oraz wyrażeń i zwrotów ${ }^{6}$. Przez „pojęcie nieostre" należy rozumieć taką konstrukcję zwrotu zawartą w wypowiedzi normatywnej, w której hipoteza czy dyspozycja są niedookreślone, a mianowicie, gdy niektóre elementy sytuacji faktycznej lub dyspozycji nie zostały w sposób bez-

\section{Ibidem, s. 27.}

3 Ibidem, s. 31.

4 L. Leszczyński, Klauzule generalne w polskim porzadku prawnym, [w:] System Prawa Administracyjnego, t. 4: Wyktadnia w prawie administracyjnym, red. R L. Leszczyński, B. Wojciechowski, M. Zirk-Sadowski, Warszawa 2012, s. 111.

5 M. Wyrzykowski, Pojęcie interesu społecznego w prawie administracyjnym, Warszawa 1986, s. 127.

6 M. Mincer, Pojęcia niedookreślone w orzecznictwie Naczelnego Sądu Administracyjnego, „Nowe Prawo" 1984, nr 7-8, s. 95. 
pośredni i wyczerpujący ustalone, lecz pozostawione ocenie stosującego prawo ${ }^{7}$. Pojęcia niedookreślone mogą wprawdzie wywoływać pewne niebezpieczeństwa, ale zarazem nadają normom prawnym bardziej elastycznego charakteru i sprawiają, że stają się one bardziej wrażliwe na rzeczywistość ${ }^{8}$.

Ustawodawca w kodeksie postępowania administracyjnego ${ }^{9}$ określa przykładowe zjawiska i sytuacje, które mogą być potraktowane jako wskazówki w procesie tworzenia treści pojęcia interesu społecznego. W art. 108 k.p.a. zostały sformułowane warunki nadania decyzji, od której służy odwołanie, rygoru natychmiastowej wykonalności. Takie rozwiązanie jest dopuszczalne, gdy jest to niezbędne ze względu na ochronę zdrowia lub życia ludzkiego albo dla zabezpieczenia gospodarstwa narodowego przed ciężkimi stratami lub też ze względu na inny interes społeczny lub wyjątkowo ważny interes strony. Należy zatem przyjąć ochronę życia lub zdrowia oraz interes strony za pojęcia samoistne. Skoro ustawodawca używa w tym przypadku określenia ,inny interes społeczny”, można uznać, że zarówno straty w gospodarstwie narodowym, jak i zabezpieczenie przed ich wystąpieniem powinno się traktować jako pewien rodzaj interesu społecznego ${ }^{10}$. Kolejną wskazówkę co do treści pojęcia interesu społecznego można wyinterpretować z działu VIII kodeksu. Według art. 241 k.p.a. przedmiotem wniosku mogą być sprawy ulepszenia organizacji, wzmocnienia praworządności, usprawnienia pracy oraz zapobiegania nadużyciom, ochrony własności, a także lepszego zaspokajania potrzeb ludności. Zgodnie z art. 221 k.p.a. wnioski można składać między innymi w interesie publicznym. Z tego względu takie wartości, jak sprawna organizacja, ochrona własności czy maksymalny poziom zaspokajania potrzeb ludności stanowią wartość równie ważną dla ogółu, czyli leżą w interesie społecznym ${ }^{11}$.

Prowadząc rozważania na temat miejsca i funkcji interesu społecznego w jurysdykcyjnym postępowaniu administracyjnym, jako punkt wyjścia należy przyjąć analizę art. 7 in fine k.p.a., na mocy którego organ administracji publicznej powinien przy załatwieniu sprawy kierować się interesem społecznym i słusznym interesem obywateli. Konstrukcja tego przepisu wprowadza obok pojęcia „interes społeczny” pojęcie „słusznego interesu obywateli”. Sformułowanie zwrotu „słuszny interes obywateli” wzbudza pewne niejasności w procesie jego interpretacji, a mianowicie, czy intencją ustawodawcy jest w tym przypadku ochrona słusznego interesu grupy obywateli czy obowiązek ten jest ograniczony jedynie do interesu jednostki - strony postępowania administracyjnego. Warto w tej sytu-

7 M. Wyrzykowski, Pojęcie interesu społecznego..., s. 49.

8 M. Zdyb, J. Stelmasiak, Zasady ogólne Kodeksu postępowania administracyjnego. Orzecznictwo Naczelnego Sądu Administracyjnego z komentarzem, Lublin 1992, s. 47.

9 Ustawa z dnia 14 czerwca 1960 r. - Kodeks postępowania administracyjnego (t.j. Dz.U. z 2013 r., poz. 267), dalej jako: k.p.a.

10 M. Wyrzykowski, Pojęcie interesu społecznego..., s. 150.

11 Ibidem, s. 151. 
acji przychylić się do poglądu, że w procesie ustalania zakresu pojęcia „słuszny interes obywateli" należy uwzględnić nie tylko słuszny interes strony postępowania administracyjnego, ale także jednostek, które mają w sprawie słuszny interes faktyczny. Wydaje się, że gdyby celem ustawodawcy była jedynie ochrona interesu strony postępowania, nie wprowadziłby on pojęcia „obywatel”. Skutkami decyzji administracyjnej jest objęta nie tylko strona postępowania administracyjnego, ale często również szereg innych podmiotów, których interesom prawo nie przyznaje rangi interesu prawnego. Obowiązek organów administracji publicznej zważania przy załatwianiu sprawy także na interesy faktyczne stanowi znaczącą dla tej kategorii interesów możliwość ochrony ${ }^{12}$. Ustawodawca, wprowadzając do k.p.a. określenie „słuszny interes obywateli”, wprowadza regułę, że ochronie podlega jedynie interes wypełniający wymogi pojęcia „słuszny”, powoduje to zatem konieczność dokonania weryfikacji tego interesu. Pojęcie „słuszny” należy uznać za dodatkowy czynnik oceniający, choć jego analiza wprowadza pewne wątpliwości interpretacyjne. $Z$ tej racji nie każdy interes obywatela powinien być uwzględniany, a jedynie interes godny ochrony, zgodny z prawem i zasadami współżycia społecznego ${ }^{13}$. Uznanie interesu za słuszny musi być w konkretnym przypadku poprzedzone jego obiektywną oceną, a nie wynikać z subiektywnego przekonania strony opartego na poczuciu krzywdy. Za naganne należy uznać korzystanie z uprawnień w sposób niezgodny z prawem, a zwłaszcza naruszający chronione dobro innych obywateli. W takich sytuacjach zostaje naruszony interes społeczny, co tym bardziej powoduje, że interes naruszającego nie może być uznany za „słuszny”"14.

Konstrukcja zasady ogólnej postępowania administracyjnego z art. 7 in fine k.p.a. została oparta na zestawieniu pojęć „słuszny interes obywateli” i ,interes społeczny”. Z racji wprowadzenia przez ustawodawcę kwalifikatora „słuszny” jedynie w stosunku do interesu obywateli może się nasuwać przypuszczenie, że budowa tego przepisu została oparta na założeniu słuszności interesu społecznego ${ }^{15}$.

Zagadnienie stosunku interesu społecznego do interesu indywidualnego oraz sposób rozwiązywania sprzeczności między nimi stanowi jedno z fundamentalnych zagadnień ustrojowych ${ }^{16}$. W doktrynie postępowania administracyjnego niejednokrotnie był dyskutowany problem dominacji interesu społecznego lub in-

12 B. Adamiak, [w:] B. Adamiak, J. Borkowski, Kodeks postępowania administracyjnego. Komentarz, Warszawa 2004, s. 71.

13 S. Rozmaryn, O zasadach ogólnych Kodeksu postępowania administracyjnego, „Państwo i Prawo" 1961, z. 12, s. 893.

14 A. Matan, [w:] G. Łaszczyca, C. Martysz, A. Matan, Kodeks postepowania administracyjnego. Komentarz, Kraków 2005, s. 205.

15 M. Wyrzykowski, Pojęcie interesu społecznego..., s. 123.

16 E. Smoktunowicz, Interes społeczny a interes strony $w$ postepowaniu administracyjnym, „Rada Narodowa” 1963, nr 31, s. 9. 
teresu obywateli. Obowiązujące rozwiązania prawne nie ustalają hierarchii wskazanych interesów, brak również określenia zasad rozstrzygania konfliktów między nimi. Z perspektywy celów postępowania administracyjnego należy przyjąć, że oba te interesy są prawnie równorzędne, zatem jednakowo podlegają ochronie, bez dominującej roli któregokolwiek z nich ${ }^{17}$. Trafnie wskazuje się, że przekonanie o immanentnej nadrzędności interesu społecznego nad interesem obywatela mogłoby oznaczać, że sytuacja osiągnięcia granicy kolizji tych interesów wykluczałaby ochronę interesu indywidualnego. Nie wydaje się zatem możliwe wyprowadzenie na gruncie obowiązujących przepisów k.p.a. kategorycznego założenia dotyczącego preferencji któregoś $\mathrm{z}$ tych interesów ${ }^{18}$. Nie znajduje się obecnie podstaw dla sztywno pojmowanej zasady nadrzędności interesu społecznego nad interesem indywidualnym. W każdym przypadku załatwiania sprawy na organie administracji publicznej ciąży obowiązek wskazania, o jaki interes społeczny chodzi, i udowodnienia, iż jest on na tyle istotny, że bezwzględnie wymaga ograniczenia uprawnień indywidualnych. Obywatel ma prawo do tego, aby jego sprawa była rozstrzygana $\mathrm{w}$ ramach opartej na prawie procedury i w określonych przez prawo formach, dlatego przesłanki powodujące konieczność przedłożenia interesu społecznego nad indywidualny zawsze muszą podlegać wnikliwej kontroli instancyjnej, a szczególnie wówczas, gdy chodzi o udowodnienie, że w interesie społecznym leży ograniczenie prawa własności ${ }^{19}$.

Podczas rozważań na temat zagadnienia interesu społecznego w postępowaniu administracyjnym niewątpliwie dominującą pozycję zajmują rozważania dotyczące relacji między interesem społecznym a interesem indywidualnym. Warto jednak zwrócić uwagę na możliwość zaistnienia kolizji między interesami społecznymi różnej rangi. Zadaniem organu administracji publicznej jest $\mathrm{w}$ takich wypadkach szukanie i zastosowanie możliwie optymalnego w danej sytuacji rozwiązania ${ }^{20}$.

Określenie wartości właściwych w konkretnej sprawie interesowi społecznemu ze słusznością interesu indywidualnego ma wyjątkowe znaczenie w podejmowaniu decyzji administracyjnych na zasadzie uznania administracyjne$\mathrm{go}^{21}$. Należy jednak rozważyć, czy zasada $\mathrm{z}$ art. 7 in fine k.p.a. ma zastosowanie do wszystkich decyzji administracyjnych czy jedynie do decyzji uznaniowych.

17 A. Wróbel, [w:] M. Jaśkowska, A. Wróbel, Kodeks postępowania administracyjnego. Komentarz, Kraków 2000, s. 133.

18 M. Wyrzykowski, ,Interes społeczny” jako kategoria proceduralna, „Acta Universitatis Wratislaviensis. Prawo" 1990, nr 1022, s. 340.

19 Wyrok SN z dnia 18 listopada 1993 r., III ARN 49/93; R. Kędziora, Kodeks postepowania administracyjnego - edycja pierwsza, Warszawa 2004, s. 40.

20 Z. Janowicz, Kodeks postepowania administracyjnego. Komentarz, Warszawa 1999, s. 72.

21 J. Borkowski, [w:] B. Adamiak, J. Borkowski, Postępowanie administracyjne i sądowoadministracyjne, Warszawa 2003, s. 35. 
Z jednej strony wyłania się stanowisko, że jeżeli ustawodawca nie pozostawia organowi swobody w ocenie obu tych interesów i sam prezentuje swoje stanowisko w normie prawnej, dochodzi do wydania decyzji związanej, przy której nie ma miejsca na własną interpretację przez organ interesu społecznego i słusznego interesu obywatela. Obowiązek wynikający z art. 7 in fine k.p.a. ma zatem zastosowanie jedynie w takich sytuacjach, gdy ustawodawca pozostawił organowi administracji publicznej swobodę $\mathrm{w}$ odnalezieniu najodpowiedniejszego sposobu załatwienia sprawy przez ocenę wymogów interesu społecznego i interesu obywateli, a więc w przypadku decyzji uznaniowych ${ }^{22}$. Z kolei w sprawach, które są rozstrzygane w drodze tzw. decyzji związanych, nie ma podstaw do stosowania zasady uwzględniania $z$ urzędu interesu społecznego i słusznego interesu obywateli ze względu na jednoznaczne zdeterminowanie treści decyzji wolą ustawodawcy ${ }^{23}$. Dyrektywa ta ma natomiast zastosowanie w sytuacji, gdy norma prawna nie wprowadza obowiązku określonego zachowania się organu, lecz pozostawia mu możliwość wyboru sposobu załatwienia sprawy ${ }^{24}$. W doktrynie postępowania administracyjnego prezentowane były również zgoła odmienne stanowiska $\mathrm{w}$ tej kwestii, a mianowicie, że wynikający $\mathrm{z}$ k.p.a. obowiązek wyważania interesu społecznego i słusznego interesu indywidualnego dotyczy wszystkich decyzji administracyjnych, zarówno uznaniowych, jak i związanych. Przez zawężenie tej dyrektywy jedynie do decyzji o charakterze uznaniowym zostałaby ograniczona możliwość działania organów administracji publicznej w tych przypadkach, w których ustawodawca jako przesłankę decyzji przyjmuje interes społeczny ${ }^{25}$.

Zasada uwzględniania interesu społecznego słusznego interesu obywateli jest jedną z kluczowych zasad postępowania administracyjnego. Wynika z niej nakaz ważenia interesu jednostki i interesu społecznego. Nie wydaje się celowe ujmowanie relacji interes indywidualny - interes społeczny w kategoriach pełnej konkurencyjności, nie jest też możliwe zaakceptowanie tezy, że państwo jest „panem i władcą" jednostki. Wspólnota jest wyznaczana również przez fakt poszanowania wartości międzyludzkich ${ }^{26}$.

Analiza treści zasady wynikającej z art. 7 in fine k.p.a. nie wyczerpuje wieloaspektowego zagadnienia interesu społecznego w jurysdykcyjnym postępowaniu administracyjnym. Ustawodawca stosuje pojęcie interesu społecznego w konstrukcji poszczególnych norm i instytucji jurysdykcyjnego postępowania administracyjnego. W przepisach k.p.a. regulujących jurysdykcyjne postępowanie ad-

22 S. Zapalska, Sprawowana przez Naczelny Sad Administracyjny kontrola decyzji uznaniowych a art. 7 in fine Kodeksu postępowania administracyjnego, „Nowe Prawo” 1985, nr 11-12, s. 35.

23 Wyrok NSA z dnia 18 grudnia 1995 r., SA/Ka 2198/94, niepubl.

24 Wyrok NSA z dnia 23 czerwca 1995 r., SA/Wr 2744/94, niepubl.

25 M. Wyrzykowski, Pojęcie interesu społecznego..., s. 135.

26 M. Zdyb, J. Stelmasiak, op. cit., s. 47. 
ministracyjne pojęcie interesu społecznego występuje w różnych konfiguracjach $\mathrm{z}$ innymi pojęciami ${ }^{27}$.

Kategoria interesu społecznego stanowi w wielu wypadkach alternatywną przesłankę do podejmowania czynności przez organ administracji publicznej ${ }^{28}$. W sytuacji ograniczenia zakresu postępowania administracyjnego po powstaniu sporu o właściwość interes społeczny stanowi podstawę do podjęcia przez organ administracji publicznej, na którego obszarze wynikła sprawa, czynności niecierpiących zwłoki ${ }^{29}$. Podobne zastosowanie przesłanki interesu społecznego przyjął ustawodawca w odniesieniu do czynności podejmowanych przez pracownika wyłączonego od udziału w postępowaniu administracyjnym ${ }^{30}$. Na mocy art. 118 k.p.a. organ administracji publicznej powinien ocenić treść ugody pod względem jej zgodności z interesem społecznym ${ }^{31}$. Z kolei - jak już wspomniano wyżej rygor natychmiastowej wykonalności może być nadany decyzji administracyjnej z uwagi na ochronę szczególnie cennych wartości (dóbr), takich jak zdrowie lub życie ludzkie, bądź określonych interesów, do których grupy ustawodawca wprowadził również kategorię interesu społecznego obok wyjątkowo ważnego interesu strony. Zdaniem NSA, ,przesłanki nadania decyzji rygoru natychmiastowej wykonalności nie mogą być interpretowane rozszerzająco, lecz muszą być poddawane wykładni ścisłej”’2.

Jeżeli przemawia za tym słuszny interes strony lub interes społeczny, decyzja ostateczna, na mocy której żadna ze stron nie nabyła prawa, może być w każdym czasie uchylona lub zmieniona przez organ, który ją wydał lub przez organ wyższego stopnia. W sytuacjach, gdy na mocy decyzji ostatecznej strona nabyła prawo, decyzja ta może być uchylona lub zmieniona jedynie za zgodą strony. W tym przypadku również interes społeczny stanowi przesłankę do jej uchylenia lub zmiany. Według NSA, ,interes społeczny lub słuszny interes strony może wyrażać się zarówno w tym, że istnieją okoliczności faktyczne interes ten uzasad-

27 M. Wyrzykowski, ,,Interes społeczny” jako kategoria..., s. 343.

${ }_{28}$ Idem, Pojęcie interesu społecznego..., s. 136.

${ }_{29}$ M. Wierzbowski, [w:] M. Wierzbowski, M. Szubiakowski, A. Wiktorowska, Postepowanie administracyjne - ogólne, podatkowe, egzekucyjne i przed sądami administracyjnymi, Warszawa 2004, s. 43.

30 A. Wróbel, [w:] K. Chorąży, W. Taras, A. Wróbel, Postępowanie administracyjne, egzekucyjne i sadowoadministracyjne, Kraków 2003, s. 50.

31 B. Adamiak, op. cit., s. 540. W doktrynie postępowania administracyjnego na wątpliwości związane z kwestią zatwierdzenia ugody przez organ administracji publicznej zwracał uwagę W. Dawidowicz, według którego traktowanie przesłanki interesu społecznego niezależnie od kwestii zgodności ugody z prawem przyznaje organowi kompetencję do odmówienia zatwierdzenia ugody, która wprawdzie została zawarta zgodnie z prawem, ale którą ocenia jako naruszającą interes społeczny. Zob. W. Dawidowicz, Postepowanie administracyjne. Zarys wyktadu, Warszawa 1983, s. 118.

32 Wyrok NSA z dnia 19 lutego 1998 r., V SA 686/97, z glosą K. Frąckiewicza, „Glosa” 1999, nr 5, s. 20. 
niające, jak i w tym, że istnieją okoliczności o charakterze prawnym wskazujące na nieadekwatność rozstrzygnięcia w stosunku do obowiązującego prawa" ${ }^{33}$. Na mocy art. 162 k.p.a. stwierdzenie wygaśnięcia bezprzedmiotowej decyzji następuje na podstawie przepisu prawa albo gdy wymaga tego interes społeczny lub interes strony ${ }^{34}$.

Klauzula interesu społecznego pojawia się także wśród przesłanek tzw. fakultatywnego przerwania toku postępowania administracyjnego, zarówno tymczasowego (zawieszenia), jak i definitywnego (umorzenia). Organ może dokonać takiego przerwania na wniosek strony, która wystąpiła z żądaniem wszczęcia postępowania, jeżeli nie sprzeciwiają się temu ewentualne inne strony oraz nie stoi temu na przeszkodzie interes społeczny (art. $98 \S 1$, art. $105 \S 2$ k.p.a.). W literaturze zwraca się uwagę na to, że zagrożenie dla interesu społecznego wynikające z przerwania toku postępowania powinno mieć charakter aktualny i rzeczywisty, a nie tylko potencjalny ${ }^{35}$.

Klauzula interesu społecznego, podobnie jak stanowisko drugiej strony (pozostałych stron) $\mathrm{w}$ kwestii zawieszenia lub umorzenia postępowania, jest sformułowana jako przesłanka negatywna, czyli jako okoliczność przemawiająca za odmową przerwania toku postępowania, a nie jako uzasadnienie przychylenia się do wniosku strony. Nie ulega zatem wątpliwości, że organ administracji publicznej jest obowiązany udowodnić, że skonkretyzowany interes społeczny sprzeciwia się zawieszeniu lub umorzeniu postępowania; nie musi zaś dowodzić, że interes ten przemawia za przerwaniem toku postępowania ${ }^{36}$. Powstaje natomiast pytanie, czy organ - przychylając się do wniosku strony - powinien wykazać, że interes społeczny nie stoi na przeszkodzie umorzeniu postępowania.

Wydaje się, że konieczność lub przynajmniej dopuszczalność dowodzenia nieistnienia określonej przesłanki negatywnej należy uzależnić od tego, czy takie dowodzenie jest celowe, a zwłaszcza czy w ogóle jest możliwe. Wykazanie nieistnienia czegoś można przeprowadzić przez udowodnienie istnienia jego negacji (np. fakt nienastąpienia czyjegoś zgonu - przez udowodnienie pozostawania tej osoby przy życiu). Zabieg taki będzie jednak możliwy tylko wtedy, gdy negacja danej okoliczności (danego faktu) da się wyrazić i określić w sposób pozytywny. Jeśli negacji danej okoliczności nie da się wyrazić i określić w sposób pozytywny, lecz jedynie jako jej zaprzeczenie, to próba dowodzenia istnienia takiej negacji byłaby tak samo pozbawiona sensu, jak próba dowodzenia nieistnienia danej okoliczności, gdyż w istocie sprowadzałaby się do tego samego. (Jałowe i absurdalne byłoby więc np. zarówno usiłowanie dowiedzenia w stosunku do określonej oso-

33 Wyrok NSA z dnia 14 kwietnia 1995 r., III SA 1115/94; R. Kędziora, op. cit., s. 342.

34 B. Adamiak, op. cit., s. 352.

35 A. Wróbel, [w:] M. Jaśkowska, A. Wróbel, op. cit., s. 543.

36 Ibidem, s. 586. 
by, że nie zachodzi przesłanka w postaci posiadania jakiejś nieoznaczonej indywidualnie rzeczy, jak i że zachodzi przesłanka w postaci braku jej posiadania.) Celowość wykazywania nieistnienia określonych okoliczności należy natomiast wiązać z częstotliwością występowania takich okoliczności w stosunku do stanu będącego zaprzeczeniem ich występowania. Decydujące jest więc, czy istnienie (występowanie) okoliczności stanowiącej przesłankę negatywną określonego działania stanowi wyją̧tek w porównaniu do stanu normalnego (naturalnego) czy też stanowi ono zasadę, a wyjątkiem jest nieistnienie takiej okoliczności. Jeżeli istnienie okoliczności będącej przeszkodą w podjęciu (wykluczającej podjęcie) określonego działania stanowi wyjątek, to podejmując takie działanie, organ stosujący prawo (organ orzekający) nie musi dowodzić, iż taka okoliczność w konkretnym przypadku nie ma miejsca. Stan będący jej zaprzeczeniem uznaje się natomiast za oczywisty zgodnie z regułami doświadczenia, na zasadzie domniemania faktycznego. W przypadku rozpatrywanej przesłanki negatywnej, tj. sprzeczności zawieszenia lub umorzenia postępowania z interesem społecznym, nie zachodzi ani możliwość, ani celowość dowodzenia jej nieistnienia, gdy organ uwzględnia wniosek strony o zawieszenie lub umorzenie. Wykazanie braku tej okoliczności (przesłanki) przez dowiedzenie istnienia jej negacji nie będzie możliwe, gdyż stan będący zaprzeczeniem sprzeczności z interesem społecznym nie wyczerpuje się w samym jej przeciwieństwie, tj. w zgodności z tym interesem ${ }^{37}$. Brak sprzeczności działania organu (w analizowanym przypadku - przerwania toku postępowania) z interesem społecznym będzie zachodził także wtedy, gdy działanie to jest obojętne (neutralne) z punktu widzenia interesu społecznego. Wykazanie zaś obojętności określonego działania dla interesu społecznego jest zadaniem niewykonalnym, gdyż wymagałoby rozpatrzenia konsekwencji tego działania przy uwzględnieniu wszystkich możliwych aspektów interesu społecznego, których katalog nie jest przecież zamknięty. Nawet gdyby wykazanie niesprzeczności przerwania toku postępowania $\mathrm{z}$ interesem społecznym było możliwe, nie zachodziłaby jednak potrzeba skorzystania z tej możliwości. Nie ulega bowiem wątpliwości, że sytuacja, w której zawieszenie lub umorzenie postępowania wszczętego $\mathrm{z}$ inicjatywy strony jest sprzeczne $\mathrm{z}$ interesem społecznym, ma charakter wyjątkowy, a zatem w pełni uzasadnione jest przyjmowanie domniemania, że czynność ta nie narusza interesu społecznego ${ }^{38}$.

37 Należy odróżniać zaprzeczenie twierdzenia od jego przeciwieństwa. Jedno z podstawowych praw logiki „,p lub $\sim$ p” dotyczy zdania i jego zaprzeczenia, a nie przeciwieństwa. Przeciwieństwo twierdzenia może oczywiście być równoważne jego zaprzeczeniu, ale nie musi. Przeciwieństwo twierdzenia równoznaczne z jego zaprzeczeniem (czyli prawdziwe dokładnie wtedy, gdy twierdzenie jest fałszywe) bywa określane w logice mianem przeciwieństwa kontradyktoryjnego. Zob. E. Tugendhat, U. Wolf, Logisch-semantische Propädeutik, Stuttgart 2004, s. 52.

38 Zob. szerzej: Z.R. Kmiecik, Oświadczenia procesowe stron w ogólnym postępowaniu administracyjnym, Lublin 2008, s. 222-224. 
Analizując funkcje, jakie pełni pojęcie interesu społecznego w jurysdykcyjnym postępowaniu administracyjnym, nie można pominąć art. 139 k.p.a., ustanawiającego zakaz reformationis in peius. Kryterium rażącego naruszenia interesu społecznego stanowi podstawę odstąpienia od zasady zakazującej reformationis in peius. W wyniku nowelizacji kodeksu z 1980 r. formuła ,sprzeczność z interesem społecznym” została zastąpiona przez „rażące naruszenie interesu społecznego"39. Naruszenie interesu społecznego musi zatem mieć w tym przypadku kwalifikowaną postać. W orzecznictwie przyjmuje się, że

[...] przewidziana możliwość odstąpienia od zakazu reformationis in peius ma charakter wyjątkowy i stanowi odstępstwo od generalnej zasady niepogarszania sytuacji prawnej strony odwołującej się. Skorzystanie przez organ z tej instytucji powinno ograniczać się do absolutnie wyjątkowych sytuacji. Zakaz reformationis in peius dotyczy szczególnie istotnych wartości. Oznacza to, że posługiwanie się w praktyce art. 139 k.p.a. powinno być poddawane wnikliwej kontroli sądów i ograniczone do sytuacji absolutnie wyjątkowych z punktu widzenia praworządności ${ }^{40}$.

W piśmiennictwie zwraca się uwagę na brak konsekwencji ustawodawcy w unormowaniu instytucji cofnięcia odwołania oraz zakazu reformationis in peius przy orzekaniu przez organ administracji w postępowaniu odwoławczym, wyrażający się w niezharmonizowaniu przesłanek negatywnych stosowania obu tych instytucji procesowych. O ile bowiem cofnięcie odwołania jest bezskuteczne, gdy zaskarżona decyzja w jakimkolwiek stopniu narusza prawo lub narusza interes społeczny, o tyle zakaz reformationis in peius nie obowiązuje tylko w przypadkach rażącego naruszenia powyższych wartości ${ }^{41}$.

Niezgodność tych unormowań powoduje, że kontynuowanie postępowania odwoławczego w wyniku nieuwzględnienia cofnięcia odwołania, gdy zaskarżona decyzja narusza prawo lub interes społeczny, ale nie w stopniu rażącym, jest na ogół bezcelowe. Końcowy rezultat takiego postępowania będzie bowiem w zdecydowanej większości przypadków identyczny, jak efekt uwzględnienia cofnięcia odwołania i w konsekwencji umorzenia postępowania - tj. uzyskanie mocy prawnej przez decyzję organu I instancji. Jeżeli zaskarżona decyzja nie narusza prawa lub interesu społecznego w sposób rażący, to - mimo nieuwzględnienia cofnięcia odwołania - organ, przystępując do merytorycznego rozstrzygnięcia sprawy, i tak nie będzie mógł wzruszyć wadliwej decyzji ze względu na zakaz reformationis in peius, a zatem utrzyma ją w mocy. Dalsze prowadzenie postępowania (mimo cofnięcia odwołania przez stronę) mogłoby doprowadzić do zmiany zaskarżonej decyzji tylko wtedy, gdy miałaby to być zmiana na korzyść strony, a więc tylko wtedy, gdy strona cofa odwołanie, choć organ I instancji, naruszając prawo lub

\footnotetext{
39 M. Wyrzykowski, ,Interes społeczny” jako kategoria..., s. 343.

40 Wyrok SN z dnia 24 czerwca 1993 r., III ARN 33/93; R. Kędziora, op. cit., s. 303.

41 Zob. J. Zimmermann, Administracyjny tok instancji, Kraków 1986, s. 93.
} 
interes społeczny, określił jej sytuację prawną w sposób mniej korzystny, niż przewiduje to prawodawca. Tego rodzaju przypadki z natury rzeczy należy zaliczyć do zupełnie wyjątkowych, co nie oznacza, że mogą mieć charakter wyłącznie hipotetyczny ${ }^{42}$.

Kategoria interesu społecznego występuje również jako alternatywna przesłanka do rozstrzygnięcia zagadnienia wstępnego przez organ administracji publicznej we własnym zakresie. Wprowadzony został w tym przypadku tryb nadzwyczajny rozstrzygania zagadnienia wstępnego. Może on być stosowany między innymi, gdy zawieszenie postępowania mogłoby spowodować niebezpieczeństwo dla życia lub zdrowia ludzkiego albo poważną szkodę dla interesu społecznego. Podkreśla się, że rozstrzygnięcie zagadnienia wstępnego w trybie nadzwyczajnym bez uprzedniego wystąpienia przesłanek uzasadniających stosowanie wspomnianego trybu stanowi naruszenie przepisów prawa procesowego ${ }^{43}$. W trakcie zawieszonego postępowania administracyjnego organ administracji publicznej może podejmować czynności niezbędne w celu ochrony pewnych wartości, między innymi w celu zapobieżenia poważnym szkodom dla interesu społecznego.

Pojęcie interesu społecznego w postępowaniu administracyjnym występuje także jako jedna z przesłanek inicjatywy procesowej organizacji społecznej. Organizacja społeczna może żądać wszczęcia postępowania administracyjnego w sprawie dotyczącej innej osoby oraz dopuszczenia jej do udziału w postępowaniu, jeżeli są łącznie spełnione dwie przesłanki: 1) jest to uzasadnione jej celami statutowymi i 2) przemawia za tym interes społeczny. Organizacje społeczne, w szczególności ekologiczne, często występują w interesie społecznym. Środowisko naturalne jest przede wszystkim dobrem wspólnym - zagrożenie dla środowiska naturalnego jest zatem stwarzaniem niebezpieczeństwa dla całego społeczeństwa ${ }^{44}$. W wielu wypadkach nie wystarczy interes społeczny zawarty w celach statutowych organizacji społecznej, niezbędne jest odrębne uznanie wartości interesu społecznego w postaci spełnienia odrębnej przesłanki jej udziału w postępowaniu. W takich sytuacjach występuje swoisty podwójny filtr ocenny. Nie można jednak wykluczyć sytuacji zaistnienia kolizji rozumienia interesu społecznego przez organizację społeczną i organ administracji publicznej $^{45}$. Z racji, że udział organizacji społecznej w postępowaniu administracyjnym nie jest obojętny dla stron, szczególnie gdy reprezentują one przeciwstawne interesy, organizacja społeczna powinna wykazać zasadność udziału w postępowaniu ${ }^{46}$. Motywem działania jednostki jest przede wszystkim ochrona

\footnotetext{
42 Zob. szerzej: Z.R. Kmiecik, Oświadczenia procesowe..., s. 452-454.

43 B. Adamiak, op. cit., s. 447.

44 K. Nowak, K. Okrasiński, Sytuacja prawna organizacji ekologicznych, Wałbrzych 2006, s. 156.

45 M. Wyrzykowski, ,Interes społeczny” jako kategoria..., s. 342.

46 J. Borkowski, [w:] B. Adamiak, J. Borkowski, Kodeks postępowania administracyjnego..., s. 258.
} 
interesu indywidualnego. Z kolei motywem działania organizacji społecznej powinna być z natury rzeczy ochrona interesu społecznego ${ }^{47}$. Niekiedy działania organizacji społecznych nie są do końca zgodne z wolą społeczną. W takich właśnie przypadkach można zaobserwować zjawisko kolizji między dwoma interesami społecznymi. W interesie ochrony środowiska, czyli dobra wspólnego, leży zaniechanie budowy autostrady. Z kolei $\mathrm{w}$ interesie społecznym innego rodzaju (np. w interesie mieszkańców) jest kontynuowanie inwestycji z innych, niekiedy równie istotnych dla dobra ogółu, pobudek. Rozwiązanie tego typu sytuacji stanowi niewątpliwie jedno z najtrudniejszych zadań współczesnej administracji.

W odróżnieniu od przesłanki celu statutowego organizacji społecznej, której stwierdzenie ma charakter obiektywny (gdyż polega na porównaniu przedmiotu postępowania z tym, co wynika mniej lub bardziej wyraźnie ze statutu bądź regulaminu danej organizacji społecznej jako cel jej działania), stwierdzenie, czy wszczęcie postępowania na żądanie organizacji społecznej jest uzasadnione interesem społecznym, ma charakter ocenny, a więc subiektywny. Przy rozstrzyganiu tej wyjątkowo mglistej kwestii w konkretnej sprawie należy mieć na względzie jako wskazówki - poniższe okoliczności:

- „interes społeczny” musi być rzeczywiście „,społeczny”, tj. odnoszący się do społeczeństwa lub jego części,

- interes niektórych członków organizacji społecznej w jej udziale w postępowaniu administracyjnym nie wyklucza przyjęcia, że przemawia za tym także „interes społeczny”,

- dla uznania, że „interes społeczny” uzasadnia w danej sprawie pozytywne rozpatrzenie wniosku danej organizacji społecznej, nie wystarcza stwierdzenie, że cele statutowe tej organizacji są zbieżne z przedmiotem postępowania,

- aby przyjąć, że ,interes społeczny” uzasadnia w danej sprawie pozytywne rozpatrzenie wniosku danej organizacji społecznej, należy uznać, że jej udział przyczyni się do lepszego wyjaśnienia sprawy, a więc że za udziałem organizacji społecznej przemawia zasada prawdy obiektywnej,

- korzyść wynikająca z udziału w postępowaniu organizacji społecznej będzie mogła zaistnieć tylko wtedy, gdy organizacja społeczna występująca do organu z wnioskiem jest merytorycznie przygotowana do konkretnej sprawy,

- nie stoi na przeszkodzie uznaniu, że „interes społeczny” uzasadnia w danej sprawie pozytywne rozpatrzenie wniosku danej organizacji społecznej, stwierdzenie konfliktu między interesem strony oraz interesem społecznym reprezentowanym przez organizację społeczną,

47 W. Brzeziński, Ochrona interesu społecznego w kodeksie postępowania administracyjnego, „Państwo i Prawo” 1961, z. 3, s. 413. 
- wykazanie przez organizację społeczną istnienia okoliczności przemawiających za jej udziałem w postępowaniu nie jest warunkiem uwzględnienia jej żądania $^{48}$.

W postępowaniu administracyjnym ustawodawca stwarza instytucjonalne gwarancje ochrony interesu społecznego. Proces wyważania przez organy administracji publicznej interesu społecznego i interesu indywidualnego niewątpliwie wpływa na realizację idei sprawiedliwości proceduralnej ${ }^{49}$. Instytucje mające na celu ochronę interesów ogólnospołecznych i indywidualnych jednocześnie pogłębiają zaufanie społeczeństwa do sprawnie działającej administracji, która uwzględnia jego interesy oraz zapewnia ich skuteczną realizację i ochronę. Istotne zagadnienie z punktu widzenia powyższych zagadnień stanowi relacja interesu społecznego do interesu publicznego oraz interesu grupowego. W literaturze wskazuje się, że interes społeczny to określenie interesu publicznego używane w dawniejszym ustawodawstwie, z czasów Polskiej Rzeczypospolitej Ludowej. Dziś natomiast nie ma przeszkód, żeby utożsamiać te pojęcia i posługiwać się pojęciem interesu publicznego ${ }^{50}$. Interes grupowy postrzega się natomiast jako rodzaj interesu społecznego albo interes społeczny w wąskim znaczeniu.

\section{KLAUZULA INTERESU SPOŁECZNEGO W POSTĘPOWANIU SĄDOWOADMINISTRACYJNYM}

Sądy administracyjne sprawują kontrolę decyzji administracyjnych i innych działań (aktów i czynności) organów administracji publicznej wyłącznie pod względem zgodności z prawem. Jest to jedna z najważniejszych okoliczności odróżniających postępowanie sądowoadministracyjne od administracyjnego postępowania odwoławczego, w którym organ II instancji bada nie tylko legalność zaskarżonej decyzji, ale także - w przypadku decyzji uznaniowej - celowość (słuszność) jej wydania, ocenianą przede wszystkim z punktu widzenia interesu społecznego i interesu strony. Obowiązek uwzględniania przez organ administracji publicznej z urzędu interesu społecznego i słusznego interesu obywateli $\mathrm{w}$ toku postępowania (w tym przy wydawaniu decyzji) wynika wprost $\mathrm{z}$ art. 7 k.p.a., mającego walor zasady ogólnej postępowania administracyjnego. Oczywiście posługiwanie się tą zasadą jest ograniczone zakresem swobody, jaki w procesie stosowania prawa wyznaczają organom prowadzącym postępowanie przepisy prawa. Celowość nie może bowiem uzasadniać naruszenia prawa, w imię

48 Zob. szerzej: Z.R. Kmiecik, Wszczęcie ogólnego postępowania administracyjnego, Warszawa 2014, s. 239-248.

49 Z. Kmieciak, Idea sprawiedliwości proceduralnej w prawie administracyjnym (założenia teoretyczne i doświadczenia praktyki), „Państwo i Prawo” 1994, z. 10, s. 58.

50 J. Zimmermann, Prawo administracyjne, Kraków 2006, s. 267-268. 
celowości uzasadnionej interesem społecznym czy indywidualnym nie można działać wbrew prawu. Na ostatnim etapie stosowania prawa, czyli przy formułowaniu treści decyzji, organ może więc i powinien kierować się interesem społecznym lub jednostkowym tylko wtedy, gdy przepisy prawa materialnego przewidują uznaniowy charakter rozstrzygnięcia. Uznanie administracyjne ma miejsce wtedy, gdy w określonym stanie faktycznym organ nie musi, lecz może podjąć określone działanie albo ma możliwość wyboru między kilkoma dopuszczalnymi działaniami.

Ponieważ, jak wspomniano, kontrola sprawowana przez sądy administracyjne jest wyłącznie kontrolą przestrzegania prawa, mogłoby się wydawać, że w postępowaniu przed sądami administracyjnymi klauzula interesu społecznego nie odgrywa roli. Tak jednak nie jest.

Po pierwsze, wynika to z faktu, że - w odróżnieniu od przedwojennych aktów dotyczących Najwyższego Trybunału Administracyjnego ${ }^{51}$ (będącego odpowiednikiem współczesnego Naczelnego Sądu Administracyjnego) - obecnie obowiązujące Prawo o postępowaniu przed sądami administracyjnymi ${ }^{22}$ (podobnie zresztą jak oba wcześniejsze akty regulujące postępowanie sądowoadministracyjne po reaktywowaniu sądownictwa administracyjnego w $1980 \mathrm{r}^{53}$ ) nie wyłącza spod kontroli sądowej „,spraw, w których władze administracyjne uprawnione są do rozstrzygania według swobodnego uznania, w granicach pozostawionych temu uznaniu"s4.

Decyzje uznaniowe podlegają zatem kontroli sądów administracyjnych, a co za tym idzie - są badane pod kątem legalności. W doktrynie przyjmuje się, że naruszenie prawa materialnego (stanowiące jedną z podstaw uchylenia decyzji przez sąd administracyjny) oznacza w przypadku decyzji uznaniowych „niewłaściwe korzystanie przez organy administracji publicznej z przewidzianego w przepisach prawa uznania administracyjnego" ${ }^{5}$. Niewłaściwe korzystanie z uznania może polegać na: a) przekroczeniu granic uznania, b) zaniechaniu wykorzystania przyznanego administracji uznania w błędnym przekonaniu, że przepis prawa nakazuje organowi podjęcie danego rozstrzygnięcia, c) wykorzystaniu uznania niezgod-

${ }^{51}$ Ustawa z dnia 3 sierpnia 1922 r. o Najwyższym Trybunale Administracyjnym (Dz.U., nr 67, poz. 600 z późn. zm.); rozporządzenie Prezydenta Rzeczypospolitej Polskiej z dnia 27 października 1932 r. o Najwyższym Trybunale Administracyjnym (Dz.U., nr 94, poz. 806 z późn. zm.).

52 Ustawa z dnia 30 sierpnia 2002 r. - Prawo o postępowaniu przed sądami administracyjnymi (t.j. Dz.U. z 2012 r., poz. 270 z późn. zm.).

53 Dział VIII Kodeksu postępowania administracyjnego, dodany ustawą z dnia 31 stycznia 1980 r. o Naczelnym Sądzie Administracyjnym oraz o zmianie ustawy - Kodeks postępowania administracyjnego (Dz.U., nr 4, poz. 8 z późn. zm.); ustawa z dnia 11 maja 1995 r. o Naczelnym Sądzie Administracyjnym (Dz.U., nr 74, poz. 368 z późn. zm.).

54 Takie sprawy wyłączały spod jurysdykcji NTA zarówno art. 3 pkt b ustawy z dnia 1922 r., jak i art. 6 pkt 2 rozporządzenia z 1932 r.

55 Z. Janowicz, op. cit., s. 602. 
nie z celami wynikającymi z ustawy (tzw. obejście władzy) bądź też z ogólnymi zasadami prawa ustalonymi w ustawodawstwie zwykłym lub w Konstytucji (np. zasada równości obywateli wobec prawa) albo w orzecznictwie sądowym ${ }^{56}$. Jeśli chodzi o wykorzystanie uznania niezgodnie z ogólnymi zasadami prawa ustalonymi w ustawodawstwie zwykłym (czytaj: w kodeksie postępowania administracyjnego ${ }^{57}$ ), to podstawowe znaczenie będzie miała tu wspomniana zasada uwzględniania z urzędu interesu społecznego i słusznego interesu obywateli (art. 7 k.p.a.). Sąd administracyjny, podobnie jak organ administracji publicznej wyższego stopnia rozpatrujący odwołanie od decyzji, będzie zatem musiał ocenić, czy organ, który wydał zaskarżoną decyzję, nie wykorzystał uznania niezgodnie z interesem społecznym. Powoduje to, że w istocie zaciera się granica między kryteriami kontroli dokonywanej w administracyjnym postępowaniu odwoławczym i kryteriami kontroli dokonywanej w postępowaniu sądowoadministracyjnym. Nawiasem mówiąc - jak słusznie zauważa Z. Janowicz - nawet funkcjonujący w okresie II Rzeczypospolitej Polskiej Najwyższy Trybunał Administracyjny, badając, czy władza administracyjna była w danym przypadku w ogóle uprawniona do działania według swobodnego uznania i czy nie przekroczyła granic tego uznania, między innymi przez działanie niezgodne z celami wynikającymi z ustawy, nierzadko wnikał jednak głęboko w sferę uznania ${ }^{58}$.

Po drugie, „interes społeczny” może być wymieniony wprost w przepisie prawnym jako przesłanka lub jedna z przesłanek podjęcia decyzji o określonej treści. W takich przypadkach ,interes społeczny” występuje jako tzw. pojęcie niedookreślone (nieokreślone, nieostre, nieoznaczone). Poza interesem społecznym stosunkowo często używanymi przez prawodawcę wyrażeniami tworzącymi pojęcia niedookreślone są: „ważne względy”, „bezpieczeństwo państwa”, „słuszny interes strony”, „w miarę potrzeby”, „stosowny wymiar”, „nieskazitelny charakter”, „zasady współżycia społecznego" i inne. Przez użycie takich wyrażeń ustawa nie przyznaje organowi, tak jak przy uznaniu, upoważnienia do dokonania wyboru miedzy równowartościowymi prawnie rozwiązaniami (tj. między podjęciem i niepodjęciem decyzji o określonej treści albo między podjęciem decyzji o określonej treści i podjęciem decyzji o alternatywnej wobec niej treści), lecz upoważnia do wiążącego ustalenia $\mathrm{w}$ drodze wykładni treści znaczeniowej pojęcia w konkretnym przypadku. W zasadzie wszystkie pojęcia (nie tylko tzw. niedookreślone) mogą mieć różną treść znaczeniową, zależnie od kontekstu, w jakim zostały użyte oznaczające je wyrazy czy zwroty ${ }^{59}$. Pojęcia niedookreślone mogą mieć różną treść znaczeniową nie tylko w zależności od kontekstu ich użycia

\footnotetext{
56 Ibidem.

7 Ibidem.

Ibidem, s. 603.

Ibidem, s. 307.
} 
w zdaniu (przepisie prawnym), ale także kontekstu sytuacyjnego (faktycznego), w jakim przepis prawa zawierający taki wyraz lub zwrot jest stosowany.

Wyrażenia, których desygnatami są pojęcia niedookreślone, są zawarte w hipotezie normy prawnej, natomiast uznanie jest wyrażone w części dyspozycyjnej normy prawnej. Wyrażenia tworzące pojęcia niedookreślone podlegają zinterpretowaniu i ustaleniu, czy stan faktyczny wypełnia tę część normy, natomiast uznanie administracyjne przejawia się wtedy, gdy podmiot stosujący normę ustala skutek prawny stwierdzonego stanu faktycznego ${ }^{60}$. Oczywiście pojęcia niedookreślone mogą występować i często występują łącznie z uznaniem administracyjnym. Wówczas zastosowanie uznania administracyjnego jest czymś wtórnym, uzależnionym od wykładni danego wyrażenia oznaczającego pojęcie niedookreślone ${ }^{61}$.

W przypadku decyzji wydanych na podstawie przepisów posługujących się pojęciami niedookreślonymi kontrola dokonywana przez sąd administracyjny jest głębsza niż w przypadku decyzji opartych na uznaniu administracyjnym.

W przypadku uznania wybór jednego z dopuszczalnych rozwiązań nie może być przez sąd kwestionowany. Na przykład w sytuacji, gdy wszyscy kandydaci ubiegający się o udzielenie danej koncesji spełniają warunki określone w przepisach prawa, a organ, dokonując wśród nich wyboru, udziela koncesji jednemu z nich, to rola sądu administracyjnego sprowadza się tylko do kontroli, czy organ zgodnie z przepisami prawa ustalił stan faktyczny, a więc należycie zbadał $i$ ustalił przesłanki, jakim odpowiadają kandydaci i należycie uzasadnił wybór. Sąd nie może zatem kwestionować celowości wyboru kandydata, któremu przyznano koncesję.

W przypadku pojęć niedookreślonych nie ma natomiast żadnej „wolnej”, tj. niepodlegającej kontroli, oceny. Sąd kontroluje nie tylko prawidłowość ustalenia stanu faktycznego, ale również dokonaną przez organ administracji publicznej ocenę danego pojęcia na tle danego stanu faktycznego. Jeżeli np. sąd - odmiennie niż organ - uważa, że w konkretnym przypadku wzgląd na „interes społeczny”, „,bezpieczeństwo państwa” czy inne użyte w hipotezie normy pojęcie niedookreślone nie przemawia za odmową wydania zezwolenia stronie, która notabene spełnia ustawowe wymogi, to może uchylić decyzję organu administracji ${ }^{62}$.

Przełomowe znaczenie dla sposobu rozumienia zakresu kontroli działań administracji sprawowanej przez sądy administracyjne oraz dla sposobu postrzegania roli interesu społecznego jako kryterium rozstrzygnięć podejmowanych w ramach (w wyniku) tej kontroli odegrał słynny wyrok NSA z dnia 11 czerwca 1981 r., w którym Sąd wyraził następujący pogląd:

60 J. Świątkiewicz, Zakres kontroli Naczelnego Sąu Administracyjnego (w świetle orzecznictwa sadowego), „Ruch Prawniczy, Ekonomiczny i Socjologiczny” 1984, nr 1, s. 38-39.

${ }_{61}$ Z. Janowicz, op. cit., s. 307.

${ }^{62}$ Ibidem, s. 309. 
W obowiązującym stanie prawnym uznanie administracyjne straciło w PRL swój dotychczasowy charakter prawny, przyjmowany do niedawna w teorii prawa administracyjnego w kraju i za granicą. Fakt, że przepisy o zasadach ogólnych k.p.a. - a zwłaszcza art. 7 - zobowiązują m.in. organy administracji państwowej do załatwienia sprawy, „mając na względzie interes społeczny i słuszny interes obywateli", ustala w innych relacjach instytucję dotychczasowego uznania administracyjnego. [...] Obrona interesu indywidualnego i jej zakres sięgają do granic kolizji z interesem społecznym - jako wartością nadrzędną w państwie socjalistycznym. Zasada ta odnosi się nie tylko do zakresu i wnikliwości postępowania wyjaśniająco-dowodowego, ale również do stosowania norm prawa materialnego, na co wskazuje zwrot o „załatwieniu sprawy”, a więc do treści rozstrzygnięcia.

Oznacza to, że jeśli w sprawach pozostawionych przez przepisy prawa materialnego uznaniu administracyjnemu interes społeczny nie stoi temu na przeszkodzie, ani nie przekracza to możliwości organu administracji w realizacji przyznanego potencjalnie uprawnienia, organ ten ma obowiązek załatwić sprawę w sposób pozytywny dla strony ${ }^{63}$.

Ta - określana w doktrynie jako awangardowa - deklaracja w nowym ustroju społeczno-politycznym, jaki nastał w Polsce po 1989 r., straciła w pewnej mierze na aktualności, ponieważ obecnie nie przyznaje się już generalnego priorytetu interesowi społecznemu nad interesami indywidualnymi, uznając, że pozycje obu tych grup chronionych interesów są prawnie równorzędne. Organy administracji publicznej powinny więc ,wyważać" te - nie zawsze zbieżne - interesy i harmonizować je, jeżeli są w konkretnym przypadku sprzeczne, a nie bez względu na okoliczności czynić zadość interesowi indywidualnemu (interesowi strony) tylko w takim zakresie, w jakim nie przekracza to granicy kolizji z interesem społecznym (chyba że przepis prawa daje wyraźny priorytet interesowi państwowemu lub społecznemu albo upoważnia organ do wydania decyzji odmownej ze względu na taki interes) ${ }^{64}$. Ponadto samo pojecie interesu społecznego jest współcześnie rozumiane nieco inaczej. Dawniej przyjmowano, że termin ,interes społeczny” w rozumieniu art. 7 k.p.a. obejmuje również ,interes państwowy" ${ }^{65}$ albo wręcz jest z nim tożsamy, zważywszy, że w nauce prawa społeczeństwo to zbiorowość ludzi, która ma określoną organizację państwową i jest wyznaczona zasięgiem władzy państwowej, a nie dowolna grupa społeczna lub cała ludzkośćc6. We współczesnym orzecznictwie przyjęto natomiast stanowisko, że nie można interesu społecznego utożsamiać $\mathrm{z}$ interesem ogólnonarodowym, regionalnym czy interesem innych zbiorowości o ogromnym zasięgu, gdyż wolność stowarzyszeń w tzw. demokratycznym państwie prawnym (art. 12 Konstytucji RP) skutkuje wielością i zróżnicowaniem interesów grupowych.

${ }_{63}$ Wyrok NSA z dnia 11 czerwca 1981 r., SA 820/81, ONSA 1981, nr 1, poz. 57.

${ }^{64}$ Z. Janowicz, op. cit., s. 69-70. Podobnie: A. Wróbel, [w:] K. Chorąży, W. Taras, A. Wróbel, op. cit., s. 30-31.

65 Z. Janowicz, op. cit., s. 67.

66 J. Lang, [w:] E. Bojanowski, J. Lang, Postepowanie administracyjne. Zarys wykładu, Warszawa 1999, s. 21. 
Jednakże częściowa utrata aktualności przytoczonego wyżej wyroku Naczelnego Sądu Administracyjnego nie dotyczy istoty (sedna) zawartego w nim stanowiska. Wyrok ten dał asumpt do rozważań, czy uzasadnione jest nadal rozróżnianie kontroli decyzji pod względem legalności od kontroli celowości. Na sympozjum sędziów NSA, z szerokim udziałem przedstawicieli nauki prawa administracyjnego, które odbyło się w Popowie w dniach 11-12 maja 1983 r., zostały wypowiedziane poglądy, że ogólne zasady postępowania administracyjnego sformułowane w kodeksie, które nakazują kierować się celowością zawartą w takich dyrektywach, jak np. obowiązek uwzględniania interesu społecznego (art. 7 k.p.a.), nadają takim określeniom, jak ,interes społeczny” charakter prawny ${ }^{67}$.

Nie ma natomiast wątpliwości co do tego, że „interes społeczny” - występujący w charakterze pojęcia niedookreślonego, a nie jako okoliczność, którą należy brać pod uwagę jako jeden z wyznaczników podejmowania decyzji uznaniowych - jest (podobnie jak inne takie pojęcia) pojęciem prawnym i jakakolwiek klasyfikacja pojęć niedookreślonych nie powinna prowadzić do ograniczenia zakresu kontroli sądowej. Pojęcia niedookreślone podlegają takiej kontroli w pełnym zakresie. Jak już podkreślano, nie mogą one być rozumiane abstrakcyjnie. Muszą być oceniane na tle całokształtu sytuacji faktycznej (wewnętrznej, a w przypadku niektórych takich pojęć, jak choćby „,interes społeczny” - także międzynarodowej), przy jednoczesnym dążeniu do obiektywizacji wszystkich istotnych elementów i okoliczności, które w sumie, w swym całokształcie (ich ciężar gatunkowy, skala, natężenie, długotrwałość występowania w czasie, zaistnienie i rozwój wydarzeń, przewidywanie ich skutków, mogących nastąpić innych wydarzeń i komplikacji itp.) dają podstawę do oceny, jaką treść i znaczenie należy nadać danemu pojęciu niedookreślonemu w konkretnym przypadku ${ }^{68}$. W wyroku z dnia 26 maja 1981 r. NSA stwierdził:

Użycie przez prawodawcę określeń prawnie niezdefiniowanych (tzw. wyrażeń nieostrych) zobowiązuje organ sprawujący kontrolę legalności decyzji wydanych na podstawie przepisów używających takich określeń - do rozważenia, czy dokonana przez organ administracji państwowej [obecnie: publicznej - przyp. aut.] ocena okoliczności sprawy nie nosi cech dowolności lub nie przekroczyła dopuszczalnej granicy swobody interpretacji tych określeń na tle konkretnego stanu faktycznego ${ }^{69}$.

Sąd administracyjny uchyli zatem decyzję jako naruszającą prawo materialne, gdy organ administracji publicznej dokonał błędnej lub niepełnej oceny pojęcia interesu społecznego na tle danego stanu faktycznego sprawy administracyjnej ${ }^{70}$.

67 J. Świątkiewicz, op. cit., s. 37.

68 Por. uzasadnienie wyroku NSA z dnia 24 maja 1985 r., II SA 993/85, „Państwo i Prawo” 1986, z. 12, s. 134.

69 Wyrok NSA z dnia 26 maja 1981 r., SA 974/81, ONSA 1981, nr 1, poz. 49.

70 Z. Janowicz, op. cit., s. 607. 
J. Borkowski, analizując istotę kontroli sprawowanej przez sądy administracyjne, zauważa, że

[...] tylko w zgoła wyjątkowych wypadkach bezpośrednie porównanie opisu zachowania rzeczywistego, wyrażonego w języku prawnym, z zachowaniem określonym w normie prawnej, pozwala na sformułowanie zwrotu stosunkowego o zgodności z prawem. W przeważającej liczbie wypadków jest to proces myślowy, w którym operuje się ocenami różnego rodzaju, z niewielkimi fragmentami opisu podejmuje się złożone i subtelne wartościowania. A ponieważ norma prawna rzadko będzie bezpośrednio rozumiana i najczęściej będzie wymagała interpretacji, wobec tego również w toku ustalania jej znaczenia będą występowały oceny (np. co do rodzaju dyrektyw interpretacyjnych). Zresztą sam przepis prawny zawiera oceny albo do nich odsyła. Oceny pojawiają się przy ustalaniu faktów i przy określeniu konsekwencji prawnych, kiedy występują tzw. luzy decyzyjne $[\ldots]^{71}$.

Dokonywana przez sądy administracyjne kontrola działań administracji (przede wszystkim decyzji administracyjnych) nie oznacza zatem czysto mechanicznej, niejako automatycznej kwalifikacji działań jako legalnych lub nielegalnych, praworządnych lub niepraworządnych. Nawet wtedy, gdy przepis prawa operuje możliwie ściśle określonymi pojęciami przy określaniu warunków takiego, a nie innego zachowania się organu administracji publicznej, nie unika się oceny i wartościowania przy wypowiadaniu przez sąd zwrotu stosunkowego o zgodności (niezgodności) z prawem podjętego przez organ działania ${ }^{72}$.

\section{KLAUZULA INTERESU SPOŁECZNEGO W POSTĘPOWANIU EGZEKUCYJNYM W ADMINISTRACJI}

Wydawać by się mogło, że sam cel i przedmiot administracyjnego postępowania egzekucyjnego lokuje interes społeczny wśród najważniejszych pojęć tej procedury. Nie może wszak ujść uwadze, że istotą tego postępowania jest przymusowe wykonanie obowiązków spoczywających na zobowiązanym. $Z$ art. 2 ustawy o postępowaniu egzekucyjnym $\mathrm{w}$ administracji ${ }^{73}$ wynika zaś, że co do zasady ów przymus dotyczy należności o charakterze publicznoprawnym. Można więc stwierdzić, że w powszechnym pojmowaniu sensu istnienia tej procedury chodzi o realizację takich obowiązków, których wykonaniem zainteresowany jest ogół społeczeństwa. Taka uproszczona logika prowadziłaby do prostej konstatacji, że interes społeczny jest w pewnym sensie wyznacznikiem większości regulacji przyjętych przez ustawodawcę w aktach normujących przebieg tego postępowania.

71 J. Borkowski, Kontrola zgodności z prawem decyzji administracyjnych sprawowana przez Naczelny Sąd Administracyjny, „Nowe Prawo” 1985, nr 9, s. 16. Por. też: M. Mincer, Uznanie administracyjne, Toruń 1983, s. 52-71.

72 J. Borkowski, Kontrola zgodności z prawem..., s. 17.

${ }^{73}$ Ustawa z dnia 17 czerwca 1966 r. o postępowaniu egzekucyjnym w administracji (t.j. Dz.U. z 2014 r., poz. 1619 z późn. zm.), dalej jako: u.p.e.a. 
Tymczasem przeprowadzona przez nas analiza przepisów ustawy o postępowaniu egzekucyjnym w administracji doprowadziła do skądinąd zaskakującego wniosku, że pojęcie „interesu społecznego” zostało użyte w tekście jedynie dwukrotnie - raz przez negację (brak zagrożenia), a drugi raz w formie wypowiedzi pozytywnej (istnienie interesu).

Po raz pierwszy w art. $56 \S 2$ u.p.e.a., który stanowi, że zawieszenie postępowania egzekucyjnego, dotyczącego obowiązku o charakterze niepieniężnym, czy to z powodu śmierci zobowiązanego, jeśli obowiązek nie jest ściśle związany $\mathrm{z}$ jego osobą, czy to z powodu utraty przez zobowiązanego zdolności do czynności cywilnoprawnych $\mathrm{w}$ razie braku jego przedstawiciela ustawowego, może nastąpić tylko wtedy, gdy nie zagraża to interesowi społecznemu.

Po raz drugi natomiast $\mathrm{w}$ art. 117 u.p.e.a. przyjęto, iż w zakresie egzekucji obowiązków niepieniężnych niektóre organy egzekucyjne mogą stosować wymienione tam środki egzekucyjne bez konieczności wystawienia tytułu wykonawczego i doręczenia zobowiązanemu postanowienia o zastosowaniu środka egzekucyjnego, między innymi jeżeli wymaga tego szczególny interes społeczny.

W pierwszym przypadku brak zagrożenia interesu społecznego stanowi podstawę do przerwania biegu postępowania egzekucyjnego, w drugim zaś istnienie ważnego interesu może uzasadniać odstąpienie od dokonania podstawowych czynności procesowych i wdrożenie tzw. przymusu natychmiastowego. Należy podkreślić, że drugi ze wskazanych przepisów wartościuje w pewien sposób pojęcie interesu społecznego, wymagając, by miał on w tym przypadku charakter „szczególny”.

Nie sposób przy tym nie wspomnieć, że ustawa w art. 64e $\S 2$ pkt 2 posługuje się dodatkowo pojęciem ,interesu publicznego”, stanowiąc, że koszty egzekucyjne mogą być umorzone, gdy przemawia za tym interes publiczny.

Tak jednostkowe posłużenie się pojęciem interesu społecznego w ustawie o postępowaniu egzekucyjnym w administracji znacznie utrudnia czynienie jakichkolwiek rozważań na temat zakresu i roli interesu społecznego w postępowaniu egzekucyjnym w administracji. Na wstępie trzeba jednak stwierdzić, że ustawodawca w żaden sposób nie definiuje tego pojęcia, pozostawiając jego dookreślenie praktyce stosowania prawa przez organy egzekucyjne. Sam sposób posłużenia się tym sformułowaniem i charakter przepisów zawierających to pojęcie nie wyklucza możliwości pokrycia się interesu społecznego z interesem prywatnym. Niemniej wydaje się, że w przypadku sprzeczności obydwu interesów ustawa egzekucyjna prymat przyznaje interesowi społecznemu.

Odmiennie od regulacji postępowania administracyjnego, która traktuje interes społeczny jako przedmiot ochrony, przytoczone przepisy administracyjnego postępowania egzekucyjnego posługują się tym pojęciem w kontekście „wyjątku od reguły", co oznacza, że stwierdzenie przez organ egzekucyjny istnienia interesu społecznego pozwala w konkretnym przypadku na odstąpienie od generalnie 
obowiązujących zasad postępowania. Nie można przy tym zapomnieć, że zwrot „interes społeczny” jest w tym przypadku klauzulą generalną, która zakłada, że organ egzekucyjny w procesie stosowania prawa przy prowadzeniu konkretnego postępowania winien odczytać konkretne wartości funkcjonujące w świadomości społecznej i zdecydować o ich hierarchii, ergo - procesować w oparciu o podstawowe reguły lub wdrożyć szczególne rozwiązania.

Choć ilość powtórzeń w tekście ustawy pojęcia interesu społecznego na to nie wskazuje, to jednak klauzula interesu społecznego na gruncie administracyjnego postępowania egzekucyjnego jest dyrektywą kierowaną do organów egzekucyjnych, które wypełniają swoje zadania w interesie publicznym. Jest to między innymi skutkiem umiejscowienia tej procedury w szeroko rozumianym prawie administracyjnym. Wynika to także z faktu stosowania w oparciu o art. 18 u.p.e.a. w sposób odpowiedni przepisów kodeksu postępowania administracyjnego, w którym zasada poszanowania słusznego interesu obywateli jest jedną z naczelnych reguł. Jednocześnie klauzula ta stanowi dla administracyjnego postępowania egzekucyjnego przesłankę wdrażania mechanizmów służących ochronie wybranych wartości, takich jak chociażby życie i zdrowie ludzkie ${ }^{74}$.

\section{BIBLIOGRAFIA}

Adamiak B., [w:] B. Adamiak, J. Borkowski, Kodeks postępowania administracyjnego. Komentarz, Warszawa 2004.

Borkowski J., [w:] B. Adamiak, J. Borkowski, Kodeks postępowania administracyjnego. Komentarz, Warszawa 2004.

Borkowski J., [w:] B. Adamiak, J. Borkowski, Postępowanie administracyjne i sqdowoadministracyjne, Warszawa 2003.

Borkowski J., Kontrola zgodności z prawem decyzji administracyjnych sprawowana przez Naczelny Sad Administracyjny, „Nowe Prawo” 1985, nr 9.

Brzeziński W., Ochrona interesu społecznego w kodeksie postępowania administracyjnego, „Państwo i Prawo" 1961, z. 3.

Choduń A., Gomułowicz A., Skoczylas A., Klauzule generalne i zwroty niedookreślone w prawie podatkowym i administracyjnym. Wybrane zagadnienia teoretyczne i orzecznicze, Warszawa 2013.

Dawidowicz W., Postępowanie administracyjne. Zarys wyktadu, Warszawa 1983.

Janowicz Z., Kodeks postepowania administracyjnego. Komentarz, Warszawa 1999.

Kędziora R., Kodeks postępowania administracyjnego - edycja pierwsza, Warszawa 2004.

Kmieciak Z., Idea sprawiedliwości proceduralnej w prawie administracyjnym (założenia teoretyczne i doświadczenia praktyki), „Państwo i Prawo” 1994, z. 10.

Kmiecik Z.R., Oświadczenia procesowe stron w ogólnym postępowaniu administracyjnym, Lublin 2008.

Kmiecik Z.R., Wszczęcie ogólnego postępowania administracyjnego, Warszawa 2014.

Lang J., [w:] E. Bojanowski, J. Lang, Postępowanie administracyjne. Zarys wyktadu, Warszawa 1999.

${ }^{74}$ Zob. A. Żurawik, ,,Interes publiczny”, ,, interes społeczny” $i$,, interes społecznie uzasadniony”. Próba dookreślenia pojęć, „Ruch Prawniczy, Ekonomiczny i Socjologiczny” 2013, nr 2, s. 57. 
Leszczyński L., Klauzule generalne w polskim porzadku prawnym, [w:] System Prawa Administracyjnego, t. 4: Wykładnia w prawie administracyjnym, red. R L. Leszczyński, B. Wojciechowski, M. Zirk-Sadowski, Warszawa 2012.

Matan A., [w:] G. Łaszczyca, C. Martysz, A. Matan, Kodeks postępowania administracyjnego. Komentarz, Kraków 2005.

Mincer M., Pojęcia niedookreślone w orzecznictwie Naczelnego Sądu Administracyjnego, „Nowe Prawo" 1984, nr 7-8.

Mincer M., Uznanie administracyjne, Torun 1983.

Nowak K., Okrasiński K., Sytuacja prawna organizacji ekologicznych, Wałbrzych 2006.

Rozmaryn S., O zasadach ogólnych Kodeksu postępowania administracyjnego, „Państwo i Prawo” 1961, z. 12.

Rozporządzenie Prezydenta Rzeczypospolitej Polskiej z dnia 27 października 1932 r. o Najwyższym Trybunale Administracyjnym (Dz.U., nr 94, poz. 806 z późn. zm.).

Smoktunowicz E., Interes społeczny a interes strony w postępowaniu administracyjnym, „Rada Narodowa" $1963, \mathrm{nr} 31$.

Świątkiewicz J., Zakres kontroli Naczelnego Sądu Administracyjnego (w świetle orzecznictwa sądowego), „Ruch Prawniczy, Ekonomiczny i Socjologiczny” 1984, nr 1.

Tugendhat E., Wolf U., Logisch-semantische Propädeutik, Stuttgart 2004.

Ustawa z dnia 3 sierpnia 1922 r. o Najwyższym Trybunale Administracyjnym (Dz.U., nr 67, poz. 600 z późn. zm.).

Ustawa z dnia 14 czerwca 1960 r. - Kodeks postępowania administracyjnego (t.j. Dz.U. z 2013 r., poz. 267).

Ustawa z dnia 17 czerwca 1966 r. o postępowaniu egzekucyjnym w administracji (t.j. Dz.U. z 2014 r., poz. 1619 z późn. zm.).

Ustawa z dnia 31 stycznia 1980 r. o Naczelnym Sądzie Administracyjnym oraz o zmianie ustawy Kodeks postępowania administracyjnego (Dz.U., nr 4, poz. 8 z późn. zm.).

Ustawa z dnia 11 maja 1995 r. o Naczelnym Sądzie Administracyjnym (Dz.U., nr 74, poz. 368 z późn. zm.).

Ustawa z dnia 30 sierpnia 2002 r. - Prawo o postępowaniu przed sądami administracyjnymi (t.j. Dz.U. z 2012 r., poz. 270 z późn. zm.).

Uzasadnienie wyroku NSA z dnia 24 maja 1985 r., II SA 993/85, „Państwo i Prawo” 1986, z. 12.

Wierzbowski M., [w:] M. Wierzbowski, M. Szubiakowski, A. Wiktorowska, Postępowanie administracyjne - ogólne, podatkowe, egzekucyjne i przed sądami administracyjnymi, Warszawa 2004.

Wróbel A., [w:] K. Chorąży, W. Taras, A. Wróbel, Postępowanie administracyjne, egzekucyjne i sadowoadministracyjne, Kraków 2003.

Wróbel A., [w:] M. Jaśkowska, A. Wróbel, Kodeks postępowania administracyjnego. Komentarz, Kraków 2000.

Wyrok NSA z dnia 26 maja 1981 r., SA 974/81, ONSA 1981, nr 1, poz. 49.

Wyrok NSA z dnia 11 czerwca 1981 r., SA 820/81, ONSA 1981, nr 1, poz. 57.

Wyrok NSA z dnia 14 kwietnia 1995 r., III SA 1115/94.

Wyrok NSA z dnia 23 czerwca 1995 r., SA/Wr 2744/94, niepubl.

Wyrok NSA z dnia 18 grudnia 1995 r., SA/Ka 2198/94, niepubl.

Wyrok NSA z dnia 19 lutego 1998 r., V SA 686/97, z glosą K. Frąckiewicza, „Glosa” 1999, nr 5.

Wyrok SN z dnia 24 czerwca 1993 r., III ARN 33/93.

Wyrok SN z dnia 18 listopada 1993 r., III ARN 49/93.

Wyrzykowski M., „Interes społeczny” jako kategoria proceduralna, „Acta Universitatis Wratislaviensis. Prawo" 1990, nr 1022

Wyrzykowski M., Pojęcie interesu społecznego w prawie administracyjnym, Warszawa 1986.

Zapalska S., Sprawowana przez Naczelny Sad Administracyjny kontrola decyzji uznaniowych a art. 7 in fine Kodeksu postęowania administracyjnego, „Nowe Prawo” 1985, nr 11-12. 
Zdyb M., Stelmasiak J., Zasady ogólne Kodeksu postępowania administracyjnego. Orzecznictwo Naczelnego Sadu Administracyjnego z komentarzem, Lublin 1992.

Zimmermann J., Administracyjny tok instancji, Kraków 1986.

Zimmermann J., Prawo administracyjne, Kraków 2006.

Żurawik A., ,Interes publiczny”, ,,interes społeczny” $i$,,interes społecznie uzasadniony”. Próba dookreślenia pojęć, „Ruch Prawniczy, Ekonomiczny i Socjologiczny” 2013, nr 2.

\section{SUMMARY}

The authors of the paper focused upon the general clause of social interest in the general administrative proceedings, as well as the proceedings before administrative courts and the administrative executive proceedings. Thus we got a comprehensive - although limited, considering the framework of the study - analysis of the function of this clause in the three main sets of proceedings constituting the system of administrative procedure. The paper discusses a complicated concept of social interest and its relationship to a concept of public interest. It must be emphasized that both of the terms mentioned above are used, among other things, in the regulations of the Code of Administrative Proceedings. The authors also analyze the questions regarding possibilities of a conflict between a social interest and an individual interest.

Keywords: social interest; public interest; general administrative proceedings; proceedings before administrative courts; administrative executive proceedings

\section{STRESZCZENIE}

Autorzy opracowania skupili swe rozważania na klauzuli generalnej interesu społecznego w ogólnym postępowaniu administracyjnym, postępowaniu sądowoadministracyjnym oraz postępowaniu egzekucyjnym w administracji. W ten sposób otrzymali kompleksową, aczkolwiek ograniczoną ze względu na ramy opracowania, analizę funkcji tej klauzuli w podstawowych postępowaniach systemu procedury administracyjnej. Artykuł wyjaśnia skomplikowane pojęcie interesu społecznego oraz jego stosunek do pojęcia interesu publicznego. Podkreślenia wymaga, że oba pojęcia występują choćby w przepisach kodeksu postępowania administracyjnego. Przedmiotem rozważań autorzy uczynili również kwestie dotyczące możliwości zaistnienia kolizji między interesem społecznym a interesem indywidualnym.

Słowa kluczowe: interes społeczny; interes publiczny; ogólne postępowanie administracyjne; postępowanie sądowoadministracyjne; postępowanie egzekucyjne w administracji 